\title{
Thymus vulgaris L. extract has antimicrobial and anti-inflammatory effects in the absence of cytotoxicity and genotoxicity
}

\author{
Jonatas Rafael de Oliveira ${ }^{\mathrm{a}, *}$, Daiane de Jesus Viegas ${ }^{\mathrm{a}}$, Ana Paula Réquia Martins ${ }^{\mathrm{a}}$, \\ Cláudio Antonio Talge Carvalho ${ }^{\mathrm{b}}$, Cristina Pacheco Soares ${ }^{\mathrm{c}}$, Samira Esteves Afonso Camargo ${ }^{\mathrm{a}}$, \\ Antonio Olavo Cardoso Jorge ${ }^{a}$, Luciane Dias de Oliveira ${ }^{a}$
}

\footnotetext{
a São Paulo State University (UNESP). Institute of Science and Technology. Department of Biosciences and Oral Diagnosis, São José dos Campos, SP, Brazi

b São Paulo State University (UNESP). Institute of Science and Technology. Department of Restorative Dentistry. São José dos Campos, SP, Brazil

${ }^{\mathrm{c}}$ Universidade do Vale do Paraíba (UNIVAP). Institute of Research and Development. São José dos Campos, SP, Brazil
}

\section{A R T I C L E I N F O}

\section{Keywords:}

Thymus vulgaris 1

Antimicrobial activity

Biofilms

Cytotoxicity

Anti-inflammatory activity

Genotoxicity

\begin{abstract}
A B S T R A C T
Objectives: This study evaluated the biological effects of the T. vulgaris L. extract., such as antimicrobial activity on planktonic cultures and mono- and polymicrobial biofilms, cytotoxicity, anti-inflammatory activity and genotoxicity.

Methods: Monomicrobial biofilms of Candida albicans, Staphylococcus aureus, Enterococcus faecalis, Streptococcus mutans and Pseudomonas aeruginosa and polymicrobial biofilms composed by $C$. albicans with each bacterium were formed for $48 \mathrm{~h}$ and exposed for $5 \mathrm{~min}$ to the plant extract. Murine macrophages (RAW 264.7), human gingival fibroblasts (FMM-1), human breast carcinoma cells (MCF-7) and cervical carcinoma cells (HeLa) were also exposed to the plant extract for $5 \mathrm{~min}$ and the cell viability were analyzed by MTT, neutral red (NR) and crystal violet (CV) assays. Interleukin-1 beta (IL-1 $\beta$ ) and tumor necrosis factor alpha (TNF- $\alpha$ ) produced by RAW 264.7 was quantified by ELISA, after $24 \mathrm{~h}$ exposure to the plant extract, both in the absence and presence of lipopolysaccharide (LPS) from Escherichia coli. Genotoxicity of the plant extract was evaluated by micronucleus formation (MN) in 1000 cells. The results were analyzed by T-Test or ANOVA and Tukey's Test $(P \leq 0.05)$. Results: All biofilms showed significant reductions in CFU/mL (colony-forming units per milliliter). Cell viability was above $50 \%$ for all cell lines. Anti-inflammatory effect on the synthesis of IL- $1 \beta$ and TNF- $\alpha$ was observed. The MN was similar or lower than the control group in all cells.

Conclusions: T. vulgaris L. extract was effective against all biofilms, promoted high cell viability, anti-inflammatory effect and presented no genotoxicity.
\end{abstract}

\section{Introduction}

T. vulgaris L. (Lamiaceae) is an aromatic perennial plant originates from the Mediterranean region (Ismaili et al., 2004), which has been used by the world population as aromatic plant, food preservative and medicinal plant (Jamali et al., 2012). Thymus species present a variety of phytocompounds responsible for numerous pharmacological activities. The major constituents are terpenes as thymol, carvacrol, $p$ cymene, $\gamma$-terpinene, caryophyllene, linalool and borneol (Jamali et al., 2012). Some of their effects were described such as antibacterial (Al Laham \& Al Fadel, 2014; de Las Mercedes et al., 2015), antiviral (Sánchez \& Aznar, 2015), antifungal (Kohiyama et al., 2015; Maissa \& Walid, 2015; Khaledi, Taheri, \& Tarighi, 2015), anti-inflammatory (Aazza et al., 2014), anticancer (Al-Menhali et al., 2015), anti-hypertensive (Alamgeer et al., 2014), antioxidant (Aazza et al., 2014), antitumor (Aazza et al., 2014), pro-apoptotic (Esmaeili-Mahani, Falahi \& Yaghoobi, 2014), anti-proliferative (Esmaeili-Mahani et al., 2014) and anti-nematode (Giarratana, Muscolino, Beninati, Giuffrida, \& Panebianco, 2014) activities.

Biofilms are microbial communities attached to biotic or abiotic surface. The integrity of the site where this microecosystem is adhered can be affected by the acids generated during the metabolism of carbohydrates from the host's diet (Ammons et al., 2014).

The accumulation of biofilm on the teeth can induce demineralization and caries development (Sun et al., 2014), especially if it is composed by $S$. mutans, one of the main responsible bacteria for this infection. C. albicans is a commensal inhabitant of mucosa, however it can be potentially pathogenic for patients who present

\footnotetext{
* Corresponding author at: Universidade Estadual Paulista (UNESP). Instituto de Ciência e Tecnologia, Departamento de Biociências e Diagnóstico Bucal Av. Engenheiro Francisco José Longo, 777 - Jardim São Dimas São José dos Campos - SP, Brazil.

E-mail address: jroliveira16@hotmail.com (J.R.d. Oliveira).
} 
immunosuppression, cancer, transplant or hospitalization for a long time. In the oral cavity, it can promote oropharyngeal candidiasis (Ramage, Mowat, Jones, Williams, \& Lopez-Ribot). S. aureus can be found in cases of periodontitis, in supra and subgingival biofilms (Cuesta, Jewtuchowicz, Brusca, Nastri, \& Rosa, 2010; Zuanazzi et al., 2010). This bacterium may also be related with infections caused by implants or biomaterials (Cuesta et al., 2010). E. faecalis is responsible for periodontal disease and infection of root canals (Atila-Pektas, Yurdaku, Gulmez, \& Gorduysus, 2013). P. aeruginosa can cause an advanced periodontitis in supragingival biofilm (da Silva-Boghossian, do Souto, Luiz, \& Colombo, 2011).

In polymicrobial biofilms, $S$. aureus can easily adhere to the hyphae of $C$. albicans, resulting in a heterotypic biofilm composed mainly by hyphae of C. albicans and S. aureus (Harriott \& Noverr, 2009). Co-isolation of $C$. albicans and Enterococcus spp. at a same site of infection was observed by Mason et al. (2012) who found a significant increase of enterococci in the intestinal microbiota of antibiotic-suppressed mice previously inoculated with $C$. albicans. In the association of $C$. albicans and $S$. mutans, the yeast can contribute to the development of the biofilm of $S$. mutans (Pereira-Cenci et al., 2008). Some studies have shown that there is a direct association between the presence of these two microorganisms and the development of caries infection (de Carvalho, Silva, Hebling, Spolidorio, \& Spolidorio, 2006; Klinke, Guggenheim, Klimm, \& Thurnheer; Marchant, Brailsford, Twomey, Roberts, \& Beighton, 2001). In cases of cystic fibrosis, the association of C. albicans and $P$. aeruginosa can cause lung function loss (Chotirmall et al., 2010).

Tumor cell lines of breast carcinoma (MCF-7) and cervical cancer (HeLa) are two of the most studied lineages worldwide. MCF-7 was named in honor of Michigan Cancer Foundation, where its generation was achieved after seven attempts by researcher Herbert D. Soule. This cell lineage is widely used by numerous research groups due its clinical features (Lee, Oesterreich \& Davidson, 2015). HeLa is considered the oldest used tumor cell, it was called in honor to Henrietta Lacks, who was the source of this tumor cell lineage (Rahbari et al., 2009).

Tumor cells are more resistant to drug action (Kars et al., 2006). In this way, new products based on medicinal plants can be an alternative to obtain therapeutic success. T. vulgaris L. methanolic extract promoted a decreased of $30 \%$ on HeLa cells, demonstrated by MTT assay (Esmaeilbeig, Kouhpayeh, \& Amirghofran, 2015). In addition, T. vulgaris L. aqueous extract showed a low cell viability in contact with MCF7 tumor cells (Berdowska et al., 2013).

Medicinal plants can significantly control the inflammatory process, promoting migration of inflammatory cells, production of chemical mediators and phagocytosis (de Oliveira et al., 2013; de Oliveira et al., 2014; de Oliveira et al., 2017; Silva, Alves, Gonçalves, Amaral, \& Poeta, 2015).

The antimutagenic effect of medicinal plants has been studied revealing a possible protective action to DNA. Some compounds of $T$. vulgaris L., such as thymol and carvacrol, have presented a protective effect to the damage of DNA caused by oxidative stress (Undeğer, Başaran, Degen, \& Başaran, 2009) or by mutagenic agents (Buyukleyla et al., 2009).

Thus, this study evaluated the antimicrobial action of T. vulgaris $\mathrm{L}$. extract on planktonic cultures and monomicrobial and polymicrobial biofilms. It was analyzed the cytotoxicity and genotoxicity of $T$. vulgaris L. extract on RAW 264.7, FMM-1, MCF-7 and HeLa cells. Also, it was verified the anti-inflammatory effect of the extract in LPS-stimulated RAW 264.7 cells.

\section{Material and methods}

\subsection{Extract}

T. vulgaris L. extract was commercially acquired (Florien, Piracicaba, Brazil) at the concentration of $200 \mathrm{mg} / \mathrm{mL}$ in propylene glycol. This extract was obtained from leaves of the plant, chemically compounded by thymol, carvacrol, linalool, geranoil, citral, tannins, organic acids, flavonoids, minerals, small amount of saponins, carotene, vitamin $\mathrm{C}$ and other components in less expressive amounts, according to manufacturer.

\subsection{Antimicrobial activity}

Antimicrobial activity was evaluated on reference strains (ATCC American Type Culture Collection) of C. albicans (ATCC 18804), S. aureus (ATCC 6538), E. faecalis (ATCC 4083), S. mutans (ATCC 35688) and $P$. aeruginosa (ATCC 15442) from the Laboratory of Microbiology and Immunology, Institute of Science and Technology/UNESP, São José dos Campos, Brazil. Strains were kept frozen $\left(-80^{\circ} \mathrm{C}\right)$ in Brain Heart Infusion broth (BHI - Himedia, Mumbai, India) with $20 \%$ glycerol, for bacteria, and Yeast Extract Peptone Dextrose broth (YPD - Himedia) with $16 \%$ glycerol, for $C$. albicans.

\subsubsection{Analyze on planktonic cultures by broth microdilution method}

This method was performed according to the Clinical and Laboratory Standards Institute (CLSI), protocols M7-A6 (CLSI, 2003) and M27-A2 (CLSI, 2002) supplemented by M27-S4 (CLSI, 2012). For this, bacteria were grown in BHI agar (Himedia) and yeast in Sabouraud dextrose agar (SD - Himedia) for $24 \mathrm{~h}$ at $37^{\circ} \mathrm{C}$, with $5 \% \mathrm{CO}_{2}$ for $S$. mutans. Then, microbial suspension was prepared in sterile saline solution $(0.9 \% \mathrm{NaCl})$ whose turbidity was adjusted to $10^{6} \mathrm{CFU} / \mathrm{mL}$ in a spectrophotometer (Micronal, São Paulo, Brazil). After, $100 \mu \mathrm{L}$ of culture medium were added in wells of a 96-well plate (TPP, Trasadingen, Switzerland), being Mueller Hinton broth (Himedia) for bacteria, and RPMI 1640 with glutamine, without bicarbonate and phenol red indicator (Himedia) buffered with MOPS [3- (N-morpholino) propanesulfonic acid] (Sigma-Aldrich, St. Louis, USA) at $\mathrm{pH} 7.0 \pm 0.1$, for yeasts. Then, $100 \mu \mathrm{L}$ of $T$. vulgaris $\mathrm{L}$. extract $(200 \mathrm{mg} / \mathrm{mL})$ were added in the first well, and a serial dilution (1:2) was started. Ten dilutions were performed. Finally, $100 \mu \mathrm{L}$ of standardized microbial suspension were added in each well. Thus, the concentration of the inoculum was approximately $5 \times 10^{5} \mathrm{CFU} / \mathrm{mL}$, for bacteria, and from $5 \times 10^{2}$ to $2.5 \times 10^{3} \mathrm{CFU} / \mathrm{mL}$, for yeast. Additionally, the evaluated concentrations of the extract were from 50 to $0.09 \mathrm{mg} / \mathrm{mL}$. Control of growth (C-, medium plus inoculum) and control of the medium $(\mathrm{C}+$, medium alone) were used. After $24 \mathrm{~h}$ incubation, the minimum inhibitory concentration (MIC) was determined in the well with no turbidity from the last well with microbial turbidity. In order to determine the minimum microbicidal concentration (MMC), $100 \mu \mathrm{L}$ of the MIC and concentrations higher than MIC were seeded on BHI or SD agar. After $48 \mathrm{~h}$ incubation, the MMC was determined by observation of microbial growth absence in plate, considering the lower concentration.

\subsubsection{Analyze on mono- and polymicrobial biofilms}

Monomicrobial biofilms of C. albicans, S. aureus, E. faecalis, S. mutans and $P$. aeruginosa, as well as polymicrobial biofilms composed by $C$. albicans associated with $S$. aureus, E. faecalis, S. mutans or P. aeruginosa were evaluated. Firstly, the strains were grown on solid medium and after in liquid medium, being BHI agar and broth, for bacteria, and SD agar and Yeast Nitrogen Base broth (YNB - Himedia), for yeast, for $24 \mathrm{~h}$ at $37^{\circ} \mathrm{C}\left(5 \% \mathrm{CO}_{2}\right.$ for $S$. mutans). Then, each microbial suspension was centrifuged at $2000 \mathrm{rpm} / 10 \mathrm{~min}$ (MPW-350, Warsaw, Poland), the supernatant was discarded and the pellet was suspended in saline solution. This step was performed twice. Then, the microbial suspension was adjusted to $10^{7} \mathrm{CFU} / \mathrm{mL}$ and $200 \mu \mathrm{L}$ were added in wells of a 96well plate, which was maintained in shaking $\left(37^{\circ} \mathrm{C}\right.$; $75 \mathrm{rpm}-$ Quimis, Diadema, Brazil) for $90 \mathrm{~min}$, for initial adhesion of the biofilms. For polymicrobial biofilms, $100 \mu \mathrm{L}$ of each standardized inoculum were added. Subsequently, the supernatant was discarded and $200 \mu \mathrm{L}$ of BHI broth or YNB broth were added for development of the biofilm, in polymicrobial biofilms equal parts of these culture media were used. 
After $24 \mathrm{~h}$ incubation, the culture medium was replaced by fresh medium and the biofilm was cultivated for $48 \mathrm{~h}$ in shaking. Then, the biofilm was exposed for $5 \mathrm{~min}$ to the T. vulgaris $\mathrm{L}$. extract $(200 \mathrm{mg} / \mathrm{mL})$ or $0.9 \% \mathrm{NaCl}$ solution, being $n=10 /$ group. After washing with sterile saline to remove affected cells by the exposure, the biofilm was disaggregated by the ultrasonic homogenizer (Sonopuls HD 2200-Bandelin Eletronic, Berlin, Germany) with 25\% power for $30 \mathrm{~s}$. The generated microbial suspension was serially diluted $(1: 10)$ and $100 \mu \mathrm{L}$ were seeded on BHI or SD agar. For polymicrobial biofilms, selective medium (agar) were used, such as SD with 1\% chloramphenicol for C. albicans, BHI with $75 \mathrm{mg} \mathrm{NaCl} / \mathrm{mL}$ of medium for $S$. aureus, Mitis salivarius with $20 \%$ sucrose and 0.2 international units (IU) of bacitracin $/ \mathrm{mL}$ of medium for $S$. mutans, m-Enterococcus (Difco) for $E$. faecalis and MacConkey (Difco) for $P$. aeruginosa. After $48 \mathrm{~h}$ incubation, the concentration of $\mathrm{CFU} / \mathrm{mL}$ was determined.

\subsection{Cell viability assays}

\subsubsection{Cell lines}

Human gingival fibroblasts (FMM-1) from the Dentistry College of University of São Paulo (USP, São Paulo, Brazil), murine macrophages (RAW 264.7) from the Rio de Janeiro Cell Bank (APABCAM, Rio de Janeiro, Brazil), human breast carcinoma cells (MCF-7) and cervical carcinoma cells (HeLa) from the Adolfo Lutz Institute (São Paulo, SP, Brazil) were used. The cells were cultured in Dulbecco's modified Eagle medium (DMEM - LGC Biotechnology, Cotia, Brazil) supplemented with $10 \%$ fetal bovine serum (Invitrogen, New York, USA) and $1 \%$ penicillin-streptomycin (Gibco, Grand Island, NY, United States). They were maintained in cell culture flasks (TPP) under incubation $\left(37^{\circ} \mathrm{C}\right.$ and $5 \% \quad \mathrm{CO}_{2}$ ) and atmospheric humidity until subconfluence. Posteriorly, the cell monolayer of RAW 264.7 was disaggregated with a cell scraper (TPP), and the cell monolayer of FMM-1, MCF-7 and HeLa cells with $0.25 \%$ trypsin-EDTA (LGC Biotechnology) for $3 \mathrm{~min}$. The suspension was centrifuged at $2000 \mathrm{rpm} / 5 \mathrm{~min}$ (Hermle - Z-300 Labnet, Edison, USA), the supernatant was discarded and the pellet was suspended in fresh medium. Then, viable cells were counted by the exclusion method with Trypan blue (0.4\%, Sigma-Aldrich).

\subsubsection{Exposure to the T. vulgaris $L$. extract}

The viable cells $\left(4 \times 10^{4}\right)$ were seed in a 96-well plate and for this $200 \mu \mathrm{L}$ of DMEM were added in each well and kept in incubator for $24 \mathrm{~h}$. After, the supernatant was discarded and T. vulgaris L. extract diluted in DMEM at 25, 50 and $100 \mathrm{mg} / \mathrm{mL}$ was added. Medium without extract was used as control $(0 \mathrm{mg} / \mathrm{mL})$. Ten replicates were performed in each experimental group. After $5 \mathrm{~min}$ exposure, the supernatant was discarded and the wells were washed with phosphatebuffered saline (PBS - LGS Biotechnology). Subsequently, cell viability assays were separately applied as described.

\subsubsection{MTT assay}

The cell viability was analyzed by the reduction of MTT salt in formazan, by reductases present in viable cells. After washing with PBS, $100 \mu \mathrm{L}$ of MTT solution [bromide of 3-(4,5-dimethylthiazol-2-yl)-2,5diphenyltetrazolium bromide] (Sigma Aldrich) at $0.5 \mathrm{mg} / \mathrm{mL}$ in PBS was added. After incubation for $1 \mathrm{~h}$, under light protection, the MTT solution was removed and $100 \mu \mathrm{L} /$ well of dimethyl sulfoxide (DMSO Sigma Aldrich) were added. Then, the plate was incubated for $10 \mathrm{~min}$, followed by shaking (Solab, Piracicaba, Brazil) for more $10 \mathrm{~min}$. The absorbance was read in spectrophotometer (Bio-Tek, Vermont, USA) at $570 \mathrm{~nm}$. The optical density values were converted to percentage of cell viability.

\subsubsection{Neutral red (NR) assay}

This method verified the lysosomal activity of viable cells by the incorporation of the NR dye in lysosomes. Thus, the NR powder (Vetec/ Sigma-Aldrich, SP, Brazil) was suspended in PBS at $20 \mu \mathrm{g} / \mathrm{mL}$.
Posteriorly, $100 \mu \mathrm{L} /$ well of this solution were added and the 96-well plate was incubated for $2 \mathrm{~h}$, under light protection. Next, the solution was removed and $100 \mu \mathrm{L} /$ well of $100 \%$ ethanol were added. After $15 \mathrm{~min}$ in shaker, the absorbance was analyzed in a spectrophotometer $(\lambda=570 \mathrm{~nm})$. The obtained values were converted to percentage of cell viability.

\subsubsection{Crystal violet (CV) assay}

By this method, it was possible to verify the cell viability by staining of DNA of viable cells. The cells were fixed for $10 \mathrm{~min}$ with $10 \%$ formaldehyde (Synth). Then, the CV powder (Synth, SP, Brazil) was suspended in water distilled at $0.2 \mathrm{mg} / \mathrm{mL}$, and $100 \mu \mathrm{L} /$ well of this solution were added on the cells. After $15 \mathrm{~min}$ incubation, the supernatant was discarded and the wells were washed with distilled water to remove all CV dye. After, $100 \mu \mathrm{L} /$ well of $100 \%$ ethanol were added and after shaking (10 $\mathrm{min})$ the absorbance was analyzed in a spectrophotometer $(\lambda=570 \mathrm{~nm})$. The obtained values were converted to percentage of cell viability.

\subsection{Anti-inflammatory activity}

\subsubsection{Preparation of the experimental groups}

RAW 264.7 cells $\left(5 \times 10^{5}\right.$ cells $\left./ \mathrm{mL}\right)$ were seeded in 24 -well plates (TPP) for 24 h. Posteriorly, in groups with no LPS (Sigma-Aldrich), the supernatant was discarded and DMEM containing T. vulgaris L. extract at 25,50 and $100 \mathrm{mg} / \mathrm{mL}$ was added and pure DMEM was used as control ( $0 \mathrm{mg} / \mathrm{mL}), n=10 /$ group. However, for groups with LPS it was added $1 \mu \mathrm{g} / \mathrm{mL}$ to the DMEM containing the plant extract at the concentrations cited above ( $n=10 /$ group). After $24 \mathrm{~h}$ incubation, the supernatants were collected and stored in microtubes at $-20{ }^{\circ} \mathrm{C}$ for later measurement of proinflammatory cytokines (IL-1 $\beta$ and TNF- $\alpha$ ).

\subsubsection{ELISA (Enzyme-Linked immunosorbent assay)}

From the supernatants, the levels of proinflammatory cytokines (IL$1 \beta$ and TNF- $\alpha$ ) were measured by means of commercial kits (R \& D Systems, Minneapolis, USA) DY401 catalog (IL-1 $\beta$ ) and DY410 catalog (TNF- $\alpha$ ), according to manufacturer's guidance. The absorbance of the wells was read in a spectrophotometer $(450 \mathrm{~nm})$. The obtained values were converted to picograms per milliliter $(\mathrm{pg} / \mathrm{mL})$, considering the standard curve values for IL- $1 \beta$ or TNF- $\alpha$. GraphPad Prism 5.0 program was used.

\subsection{Genotoxicity by micronucleus (MN) assay}

MN are DNA fragments located around and close to the cell nucleus (Fig. 6A). The MN presence characterizes DNA damage. This assay was performed in all cell lineages separately. For this, DMEM containing $2 \times 10^{4}$ cells $/ \mathrm{mL}$ was added in 24 -well plate and after $24 \mathrm{~h}$ incubation the supernatant was discarded and DMEM containing T. vulgaris L. extract at $25,50,100 \mathrm{mg} / \mathrm{mL}$ or pure DMEM $(0 \mathrm{mg} / \mathrm{mL})$ was added ( $n=2$ /group). After $24 \mathrm{~h}$, the supernatant was discarded, the monolayer was washed with PBS and fixed with $10 \%$ formaldehyde for $10 \mathrm{~min}$ at room temperature. After, the plate was washed with $200 \mu \mathrm{L}$ of PBS and one drop of Fluoroshield with DAPI (Sigma-Aldrich) was added in each well. Protected from the light, the plates were agitated for $5 \mathrm{~min}$. Then, the quantity of MN was verified in 1000 cells, with fluorescence microscope (Axiovert 200 - Zeiss, Jena, Germany).

\subsection{Statistical analysis}

The results were presented as mean values ( \pm standard deviation) and statistically analyzed by GraphPad Prism 5.0 and Minitab 17, considering statistically significant difference when $P \leq 0.05$. Antimicrobial activity data were analyzed by T-Test or ANOVA complemented by Tukey's Test. Cell viability, anti-inflammatory activity and genotoxicity data were analyzed by ANOVA and Tukey's Test. 

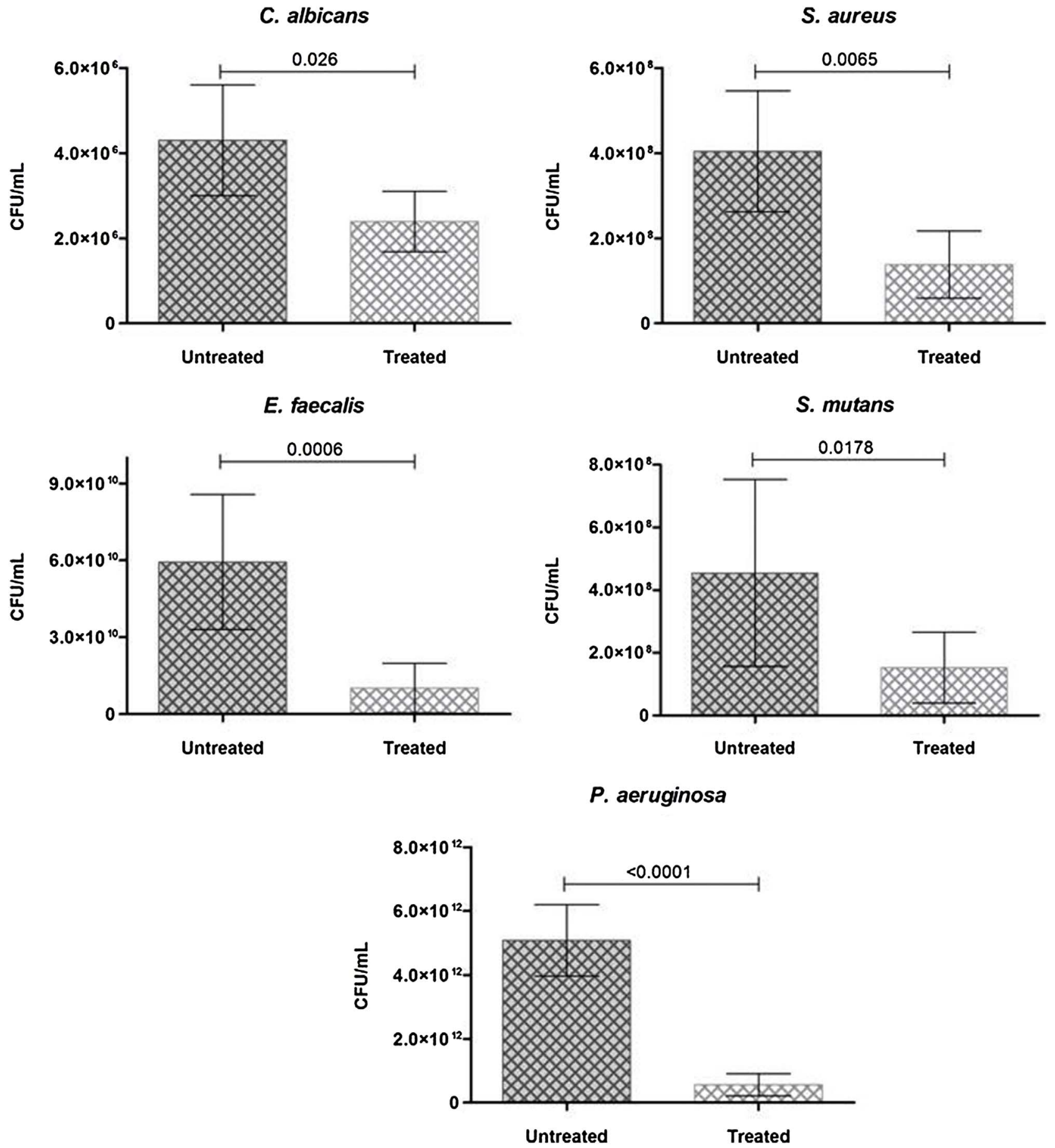

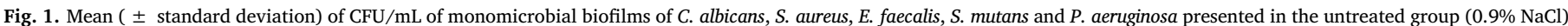
and in the treated group with T. vulgaris L. extract $(200 \mathrm{mg} / \mathrm{mL})$ for $5 \mathrm{~min} P$ values follow on the columns $(n=10$. T-Test, $P \leq 0.05)$.

\section{Results}

\subsection{Antimicrobial activity}

T. vulgaris L. extract at $50 \mathrm{mg} / \mathrm{mL}$ promoted growth inhibition of $C$. albicans. However, the MIC and MMC values were $>50 \mathrm{mg} / \mathrm{mL}$ for the other microorganisms. Regarding to monomicrobial biofilms of $C$. albicans, S. aureus, E. faecalis, S. mutans and $P$. aeruginosa, there was a significant reduction in the number of $\mathrm{CFU} / \mathrm{mL}$ after $5 \mathrm{~min}$ exposure to the T. vulgaris L. extract ( $200 \mathrm{mg} / \mathrm{mL})$ compared to the untreated group (Fig. 1 and 2).

Polymicrobial biofilms composed by C. albicans with $S$. aureus, E. faecalis, S. mutans or P. aeruginosa also showed significant reductions in $\mathrm{CFU} / \mathrm{mL}$ after exposure to T. vulgaris L. extract $(200 \mathrm{mg} / \mathrm{mL})$ for $5 \mathrm{~min}$ compared to the control group (Fig. 3). The reduction of the yeast and bacterium in polymicrobial biofilms was similar, except for the association of $C$. albicans with $P$. aeruginosa (Fig. 4).

\subsection{Cell viability}

The cell viability percentages can be verified by the MTT (Fig. 5A), NR (Fig. 5B) and CV assays (Fig. 5C), in the groups treated at different concentrations of $T$. vulgaris L. extract. $(25,50$ and $100 \mathrm{mg} / \mathrm{mL})$ and control group $(0 \mathrm{mg} / \mathrm{mL})$. It was observed a decrease in the cell 


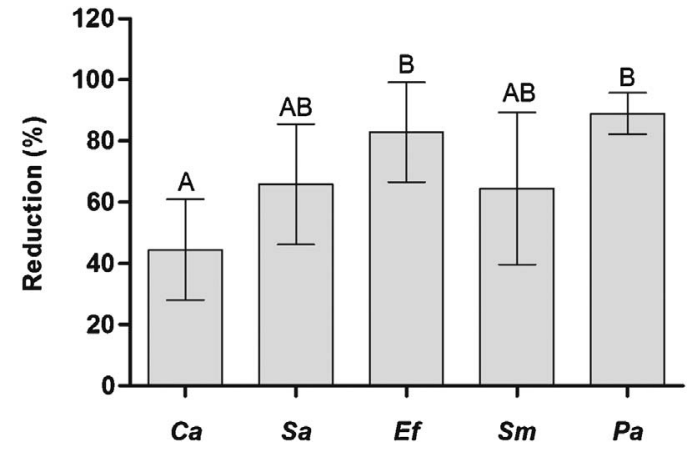

Fig. 2. Reduction percentage of monomicrobial biofilm of $C$. albicans ( $\mathrm{Ca}$ ), S. aureus (Sa), E. faecalis $(\mathrm{Ef}), \mathrm{S}$. mutans $(\mathrm{Sm})$ e $P$. aeruginosa $(\mathrm{Pa})$ after exposure to the $T$. vulgaris $\mathrm{L}$ extract. $(200 \mathrm{mg} / \mathrm{mL})$ for $5 \mathrm{~min}$. Different superscript letters indicate statistically significant differences between experimental groups. $(n=10$. ANOVA, Tukey's Test, $P \leq 0.05)$.

viability percentage of RAW 264.7 at 100 (MTT, NR and CV), 50 (MTT, $\mathrm{NR}$ and $\mathrm{CV}$ ) and $25 \mathrm{mg} / \mathrm{mL}$ (MTT). For FMM-1 cells was observed a decrease of the cell viability percentage after exposure to 100 (MTT and $\mathrm{CV}$ ), 50 (MTT and CV) and $25 \mathrm{mg} / \mathrm{mL}$ (MTT and CV), however in the NR assay there was no significant cell viability reduction. Regarding to the MCF-7, the cell viability reduction was observed after contact with concentration of 100 (MTT, NR and CV), 50 (MTT and NR) and $25 \mathrm{mg}$ / $\mathrm{mL}(\mathrm{NR})$. On the HeLa was verified cell viability decrease with application of 100 (MTT and NR) and $50 \mathrm{mg} / \mathrm{mL}$ (NR and CV). Additionally, it was found that in all experimental groups there was cell viability above $50 \%$.

\subsection{Anti-inflammatory activity}

The production of pro-inflammatory cytokines (IL-1 $\beta$ and TNF- $\alpha$ )

\section{$\mathrm{Ca}+\mathrm{Sa}$}

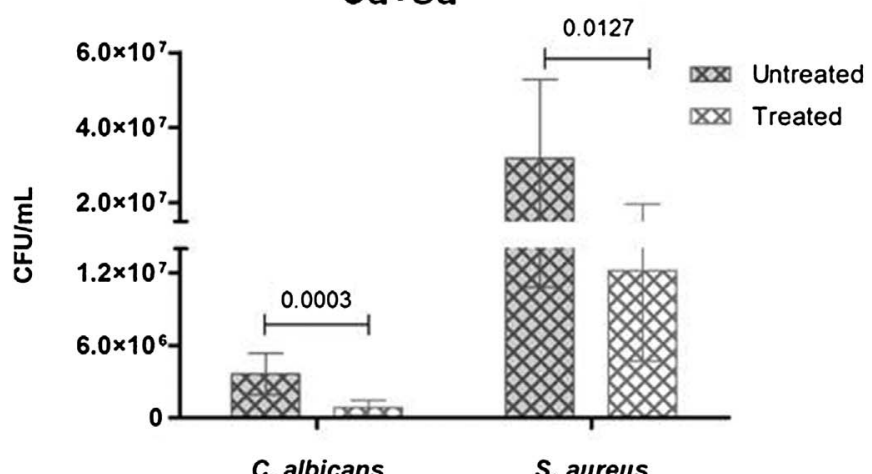

C. albicans

S. aureus

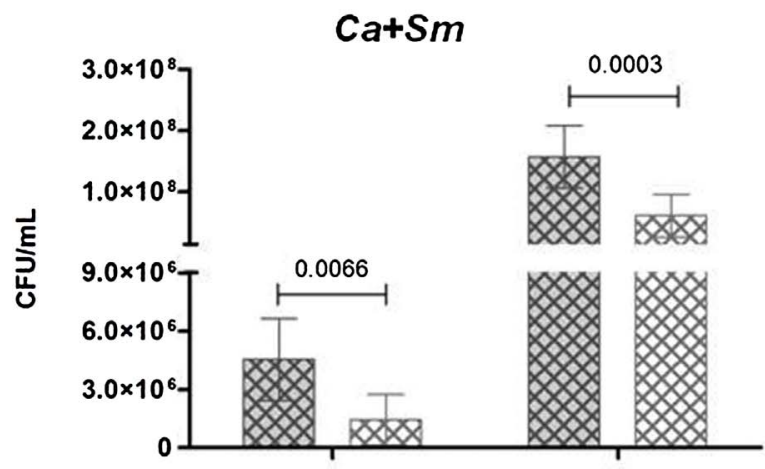

C. albicans

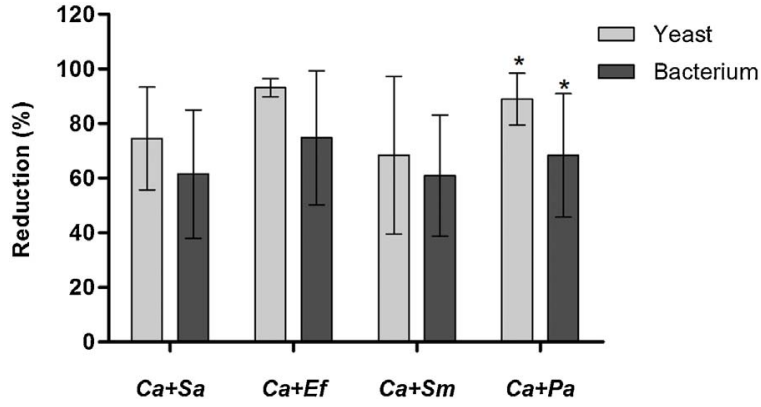

Fig. 4. Reduction percentage of polymicrobial biofilm of $C$. albicans associated with $S$. aureus $(\mathrm{Ca}+\mathrm{Sa})$, E. faecalis $(\mathrm{Ca}+\mathrm{Ef}), \mathrm{S}$. mutans $(\mathrm{Ca}+\mathrm{Sm})$ or $\mathrm{P}$. aeruginosa $(\mathrm{Ca}+\mathrm{Pa})$. It is possible to analyze the reductions of yeast and each bacterium after exposure to $T$. vulgaris L. extract $(200 \mathrm{mg} / \mathrm{mL}$ ) for $5 \mathrm{~min}$. Asterisks indicate statistically significant difference among the reductions of yeast and bacterium in each polymicrobial association. $(n=10$. T-Test, $P \leq 0.05)$.

after $24 \mathrm{~h}$ exposure to the T. vulgaris L. extract at 25,50 and $100 \mathrm{mg} / \mathrm{mL}$ was described in Table 1 . The data revealed an increase of levels of IL$1 \beta$ at $100 \mathrm{mg} / \mathrm{mL}$. However, the synthesis of this cytokine was inhibited in the treated and LPS-stimulated groups. The plant extract also promoted significant inhibition of TNF- $\alpha$. In addition, the concentrations of the extract presented an inhibitory effect on the production of this cytokine in the LPS-stimulated groups. These findings indicate an antiinflammatory action of $T$. vulgaris $\mathrm{L}$. extract.

\subsection{Genotoxicity}

The MN frequency demonstrated by RAW 264.7, FMM-1, MCF-7 and HeLa after $24 \mathrm{~h}$ contact to the T. vulgaris L. extract at 25, 50 and $100 \mathrm{mg} / \mathrm{mL}$ can be observed in Fig. 6B. The MN frequency in the cell lineages was similar in all experimental groups, except on FMM-1 that

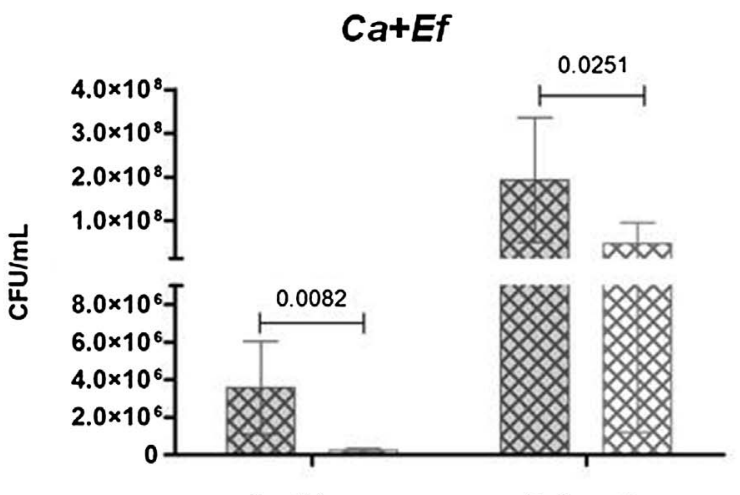

C. albicans

E. faecalis

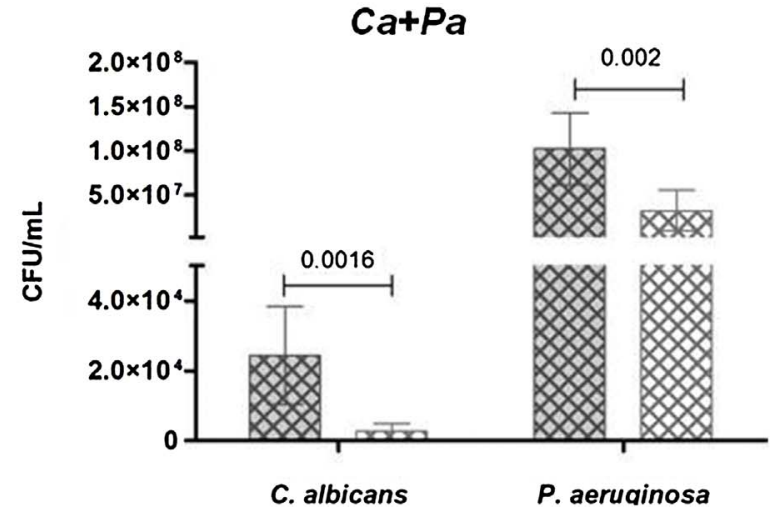

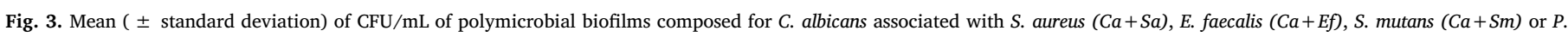

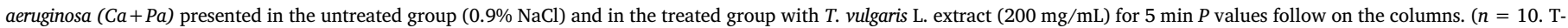
Test, $P \leq 0.05)$. 
A

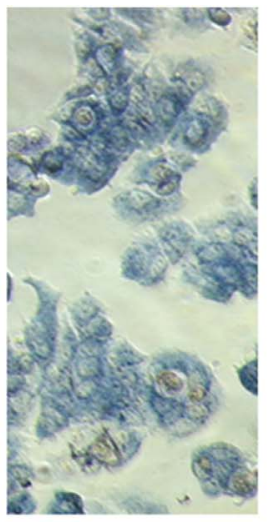

B

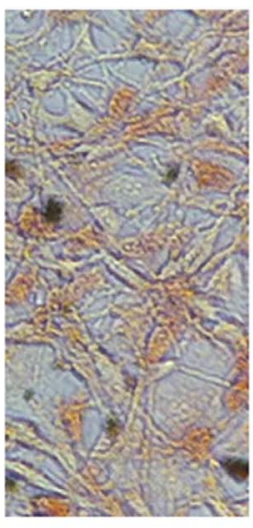

C

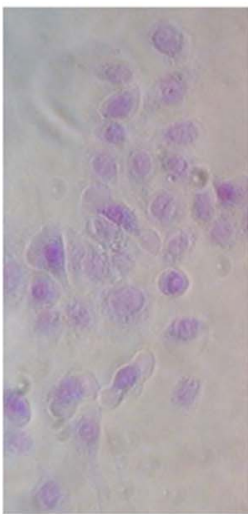

$\mathrm{MTT}$

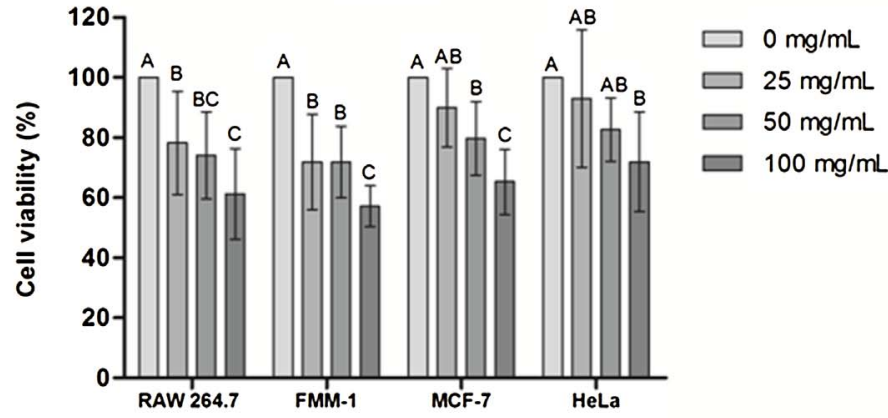

NR

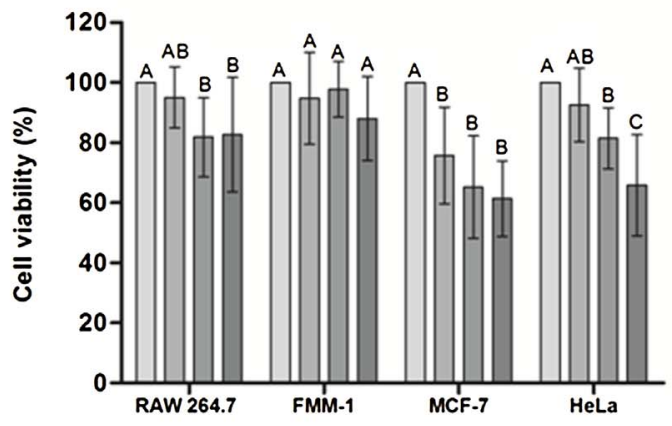

CV

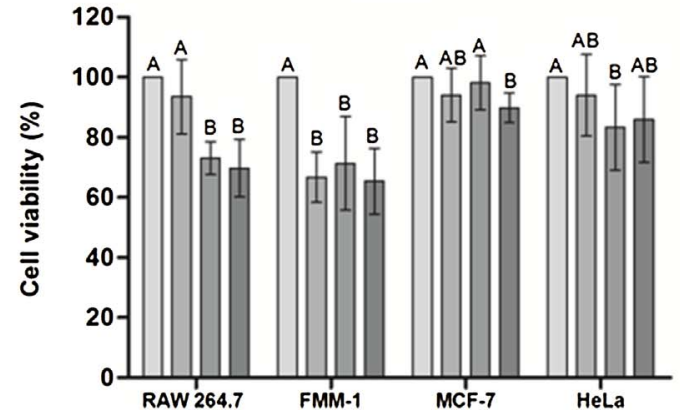

Fig. 5. Cell viability percentage of RAW 264.7, FMM-1, MCF-7 and HeLa obtained after exposure to the different concentrations of $T$. vulgaris $\mathrm{L}$. extract for $5 \mathrm{~min}$. Assays of MTT salt reduction in formazan (A), incorporation of $\mathrm{VN}$ in lysosomes (B) and DNA staining by CV (C) were performed. Different superscript letters indicate statistically significant differences among experimental groups. $(n=10$. ANOVA, Tukey's Test, $P \leq 0.05)$. Optical microscopy $(200 \times)$. showed lower MN formation at $50 \mathrm{mg} / \mathrm{mL}$ compared to $25 \mathrm{mg} / \mathrm{mL}$ and control $(0 \mathrm{mg} / \mathrm{mL})$. In addition, there was no MN formation at $100 \mathrm{mg}$ / $\mathrm{mL}$.

\section{Discussion}

In this study, T. vulgaris L. extract showed antimicrobial effect on biofilms, presenting significant reductions of $\mathrm{CFU} / \mathrm{mL}$ in monomicrobial biofilms of C. albicans, S. aureus, E. faecalis, S. mutans and $P$.
A

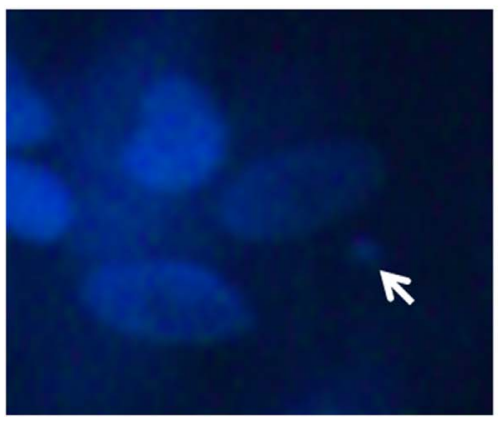

B

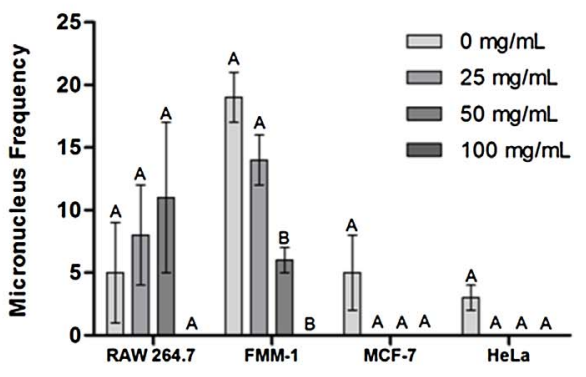

Fig. 6. Micronucleus (MN) frequency in 1000 cell obtained in the untreated $(0 \mathrm{mg} / \mathrm{mL})$ and treated (T. vulgaris $\mathrm{L}$. extract at 25,50 and $100 \mathrm{mg} / \mathrm{mL}$ ) groups for $24 \mathrm{~h}$. (A) White arrow indicates a MN developed around and close to the cell nucleus viewed by fluorescence microscopy $(200 \times)$ after addition of DAPI. (B) MN frequency obtained from the cell lines after contact with plant extract. Different superscript letters indicate statistically significant differences among experimental groups. ( $n=2$. ANOVA, Tukey's Test, $P \leq 0.05$ ). 
Table 1

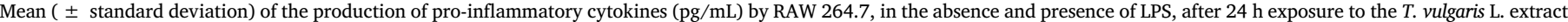

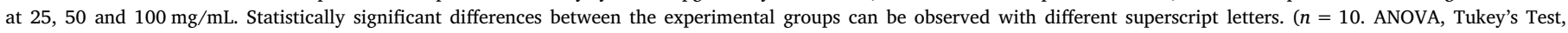
$P \leq 0.05)$.

\begin{tabular}{|c|c|c|c|c|}
\hline \multirow[t]{3}{*}{ Group (mg/mL) } & \multicolumn{4}{|c|}{ Cytokine (pg/mL) } \\
\hline & \multicolumn{2}{|l|}{ IL-1 $\beta$} & \multicolumn{2}{|l|}{ TNF- $\alpha$} \\
\hline & no LPS & LPS & no LPS & LPS \\
\hline 0 & $1.97 \pm 0^{\mathrm{B}}$ & $70.42 \pm 14.75^{\mathrm{A}}$ & $501.23 \pm 98.31^{\mathrm{A}}$ & $22140.37 \pm 788.51^{\mathrm{A}}$ \\
\hline 25 & $1.97 \pm 0^{\mathrm{B}}$ & $28.03 \pm 8.59^{\mathrm{B}}$ & $94.82 \pm 13.92^{\mathrm{B}}$ & $4466.91 \pm 155.25^{\mathrm{B}}$ \\
\hline 50 & $1.97 \pm 0^{\mathrm{B}}$ & $2 \pm 0.11^{\mathrm{C}}$ & $158.41 \pm 62.07^{\mathrm{B}}$ & $824.40 \pm 198.88^{\mathrm{C}}$ \\
\hline 100 & $3.03 \pm 1.72^{\mathrm{A}}$ & $2 \pm 0.11^{\mathrm{C}}$ & $4.94 \pm 7.19^{\mathrm{C}}$ & $12.16 \pm 29.08^{\mathrm{D}}$ \\
\hline
\end{tabular}

aeruginosa (Figs. 1 and 2) and polymicrobial biofilms (Figs. 3 and 4) composed by $C$. albicans associated with $S$. aureus, E. faecalis, $S$. mutans and $P$. aeruginosa.

T. vulgaris L. has been demonstrated effective action on microbial biofilms, as observed in our study. Khan, Ahmad, Cameotra, and Botha (2014) showed that $T$. vulgaris L. essential oil provided in vitro inhibition of biofilm formation of clinical isolates of $C$. albicans being considered resistant to antifungal. The authors considered the biofilm formation as "weak", "moderate" or "strong" and from the clinical isolates 13 were "strong" or "moderate", three were "weak" and two did not form biofilms. Additionally, sub-MIC of the essential oil were applied on the "strong" strains and caused significant biofilm reductions between $7.5 \%$ and $25 \%$.

T. vulgaris L. essential oil also was effective against biofilms of $S$. aureus and $P$. aeruginosa, demonstrating better effect than ampicillin (Kavanaugh \& Ribbeck, 2012). These authors demonstrated significant reductions of these biofilms, as it was presented on our study, despite we used glycolic extract.

We found a significant reduction of $S$. mutans biofilm after treatment with T. vulgaris L. extract. However, it was verified that this plant extract can also impair the initial adherence of this bacterium and consequently prevent biofilm formation (Hammad, Sallal \& Darmani, 2007). These authors found that the aqueous extract of this plant promoted decrease of the biofilm viability, nearly $96 \%$ after $48 \mathrm{~h}$ exposure. Nevertheless, we demonstrated inhibition of almost 70\%, after $5 \mathrm{~min}$ exposure.

In the present study, the effect of the plant extract on biofilm of $E$. faecalis or its association with $C$. albicans caused significant reductions compared to the untreated group. In the literature this effect has not been reported yet, only its action in planktonic culture has been mentioned (Melo et al., 2015; Silva et al., 2013).

Different species of microorganisms in a polymicrobial biofilm can increase the resistance to antimicrobial agents or to the host's immune system (Harriott \& Noverr, 2009), however, in this study the T. vulgaris extract decreased the resistance provided by the biofilm, resulting in cell reduction after exposure to this extract (Fig. 2 and 4). The association of microorganisms can interfere in the development of each other (Mastropaolo et al., 2005; O'Connell et al., 2006). In this way, we found that the associations of $C$. albicans with bacterium promoted a reduction of yeast compared to its monomicrobial biofilm. Also, it was noted that the reduction of the bacteria remained similar to their monomicrobial biofilms. In polymicrobial biofilms, the reduction percentages were similar between yeast and bacterium, except for the association of $C$. albicans with $P$. aeruginosa, which the yeast presented higher reduction than the bacterium. In this case, it can be suggested that substances, as phenazine, produced by $P$. aeruginosa can interfere with the process of cellular respiration and hyphae formation of $C$. albicans in this biofilm (Morales et al., 2013).

Regarding to the cell viability of RAW 264.7, FMM- 1, MCF -7 and HeLa after exposure to the extract, three different assays were used: MTT, for reduction of MTT salt in formazan, by enzymatic activity; NR, by the incorporation of NR dye in lysosomes; and CV that promotes the staining of the DNA. These products are metabolized or incorporated only by viable cells. It was observed that the plant extract at 25,50 and $100 \mathrm{mg} / \mathrm{mL}$ provided cell viability above $50 \%$ (Fig. 5). Thus, we verified that the concentrations of $T$. vulgaris L. extract significantly affected the lysosomal activity of MCF-7 and HeLa. Therefore, new studies on alternative therapies can be developed, considering the lysosomes as a possible target for interaction with therapeutic molecules, once many medications reach this cellular structure by endocytosis. These medications can also be inactivated by enzymatic degradation, especially by acid hydrolases, or its entry in the cytosol controlled by these enzymes (Duncan \& Richardson, 2012; Luzio, Pryor \& Bright, 2007).

Analysis performed by the CV assay identified that MCF-7 and HeLa showed higher cell viability percentage than other cells at $100 \mathrm{mg} / \mathrm{mL}$. MCF-7 was less affected by $50 \mathrm{mg} / \mathrm{mL}$ and FMM- 1 showed lower cell viability percentage than other cells, after treatment with $25 \mathrm{mg} / \mathrm{mL}$. Thus, we suggest that some concentrations of the plant extract did not produce significant DNA damage, mainly to MCF-7 and HeLa, which exhibited greater resistance to the damage in their genetic material than other cells. Thereby, it would be necessary use another target to promote their elimination. It was reported that tumor cell lines are able to develop multidrug resistance (Kars et al., 2006), due a complex network of proteins that regulate several resistance mechanisms and controls of apoptosis (Ding, Yang, Pater, \& Tang, 2000). HeLa has shown resistance to the action of plant products, such as T. vulgaris $\mathrm{L}$. extract, exhibiting low cytotoxicity (Esmaeilbeig et al., 2015), therefore higher concentrations of this extract could control its proliferation (Berrington \& Lall, 2012).

In the analysis of anti-inflammatory activity of the T. vulgaris L. extract, RAW 264.7 cells were exposed to LPS $(1 \mu \mathrm{g} / \mathrm{mL})$, in order to induce secretion of proinflammatory cytokines (IL-1 $\beta$ and TNF- $\alpha$ ). There was also exposure to different concentrations of the $T$. vulgaris $\mathrm{L}$. extract to verify their inhibitory effect on this secretion (Table 1). It is verified that the production of $\mathrm{IL}-1 \beta$ increased at $100 \mathrm{mg} / \mathrm{mL}$ in the non-LPS-stimulated group compared to the other concentrations. Nevertheless, in LPS-stimulated groups was observed that all concentrations were able to control significantly the production of this cytokine. Likewise, the plant extract provided inhibition of the TNF- $\alpha$ synthesis in the presence and absence of LPS. All evaluated concentrations were able to inhibit the production of this cytokine, even in the non-LPS-stimulated group. In LPS-stimulated group the inhibition was directly proportional to the concentration used. Therefore, we could demonstrate the anti-inflammatory property of the $T$. vulgaris $\mathrm{L}$. extract.

Anti-inflammatory effect of T. vulgaris, T. zygis and T. hyemalis extracts had been also confirmed by Ocaña and Reglero (2012). They identified significant reduction of proinflammatory cytokines (IL-1 3 , IL6 and TNF- $\alpha$ ) and increase of anti-inflammatory cytokine (IL-10) after $24 \mathrm{~h}$ exposure to the extracts by human monocytes (THP-1). These cells were differentiated into macrophages by phorbol myristate acetate and 
stimulated by oxidized low-density lipoprotein (LDL-oxy). In addition, the levels of IL-1 $\beta$ and TNF- $\alpha$ were similar to the baseline level of nonactivated cells after $48 \mathrm{~h}$ treatment. Anti-inflammatory activity of $T$. vulgaris $\mathrm{L}$. is not only restricted to their extracts, since the essential oil from this plant has also demonstrated effectiveness to control the production of IL-1 $\beta$, IL- 8 and TNF- $\alpha$ by LPS- or Propionibacterium acnesstimulated THP-1 (Tsai, Lin, Lin, \& Yang).

Regarding the possible of DNA damage caused by exposure to the $T$. vulgaris L. extract, it was observed the MN frequency per 1000 cells (Fig. 6). In all evaluated cell lineages, the MN frequency of treated groups $(25,50$ and $100 \mathrm{mg} / \mathrm{mL})$ was similar or lower than the untreated group $(0 \mathrm{mg} / \mathrm{mL})$. Therefore, we suggest that this plant extract provided DNA-protective effect, eliminating the possibility of neoplastic changes in non-tumor cells. In addition, in MCF-7 and HeLa there was only $\mathrm{MN}$ formation in the control group, demonstrating that the extract can also inhibit the DNA damage of these cells and contribute to decrease of mutagenicity. This protective effect has been demonstrated by the thymol, the major phytocompound present in T. vulgaris L., suggesting that it is one of the responsible for the protection to the DNA damage. This was demonstrated in keratinocytes (NCTC 2544) previously treated with thymol or T. vulgaris L. extract and posteriorly irradiated with ultraviolet light $\mathrm{A}$ and $\mathrm{B}$. The $\mathrm{MN}$ formation was significantly similar to the untreated group, demonstrating the protective effect of both products (Calò, Visone \& Marabini, 2015). This effect was also observed on human lymphocytes, after exposure to different concentrations of thymol for $48 \mathrm{~h}$. The MN formation was significantly lower than the group exposed to ethyl methanesulfonate considerate an inductor of mutagenicity (Buyukleyla \& Rencuzogullari, 2009).

The effective biological activities of T. vulgaris L. extract found in this study suggest its use on future applications, especially in the addition of this product in medical and dental materials, in order to improve them or replace ineffective and harmful products.

\section{Conclusion}

T. vulgaris L. extract exhibited effective biological activities. In this study, it was found that this plant extract at $200 \mathrm{mg} / \mathrm{mL}$ acted effectively on the control of monomicrobial biofilms of $C$. albicans, $S$. aureus, E. faecalis, S. mutans and $P$. aeruginosa and polymicrobial biofilms composed by C. albicans with $S$. aureus, E. faecalis, S. mutans or P. aeruginosa, presenting significant reductions in $\mathrm{CFU} / \mathrm{mL}$. It was also observed that the extract at 25,50 and $100 \mathrm{mg} / \mathrm{mL}$ promoted cell viability above 50\% in RAW 264.7, FMM- 1, MCF -7 and HeLa cells, anti-inflammatory effect, controlling the levels of proinflammatory cytokines (IL-1 $\beta$ and TNF- $\alpha$ ) produced by LPS-stimulated RAW 264.7 and absence of genotoxicity for the analyzed cell lineages.

\section{Acknowledgments}

We thank FAPESP (Fundação de Amparo à Pesquisa do Estado de São Paulo, Brazil) for research grant number 2015/08776-3 and Scientific Initiation grant number 14/22149-9.

\section{References}

Aazza, S., Lyoussi, B., Megías, C., Cortés-Giraldo, I., Vioque, J., Figueiredo, A. C., et al. (2014). Anti-oxidant: Anti-inflammatory and anti-proliferative activities of Moroccan commercial essential oils. Natural Product Communications, 9, 587-594.

Al Laham, S. A., \& Al Fadel, F. M. (2014). Antibacterial activity of various plants extracts against antibiotic-resistant Aeromonas hydrophila. Jundishapur Journal of Microbiology, 7, e11370.

Al-Menhali, A., Al-Rumaihi, A., Al-Mohammed, H., Al-Mazrooey, H., Al-Shamlan, M. AlJassim, M., et al. (2015). Thymus vulgaris (Thyme) inhibits proliferation, adhesion, migration: And invasion of human colorectal cancer cells. Journal of Medicinal Food, $18,54-59$.

Alamgeer, A., Jabeen, M. S., Khan, Q., Maheen, H. U., Haroon-Ur-Rash, S., et al. (2014). Pharmacological evaluation of antihypertensive effect of aerial parts of Thymus linearis benth. Acta Poloniae Pharmaceutica, 71, 677-682.

Ammons, M. C., Tripet, B. P., Carlson, R. P., Kirker, K. R., Gross, M. A., Stanisich, J. J., et al. (2014). Quantitative NMR metabolite profiling of methicillin-resistant and methicillin-susceptible Staphylococcus aureus discriminates between biofilm and planktonic phenotypes. Journal of Proteome Research, 13, 2973-2985.

Atila-Pektas, B., Yurdaku, I. P., Gulmez, D., \& Gorduysus, O. (2013). Antimicrobial effects of root canal medicaments against Enterococcus faecalis and Streptococcus mutans. International Endodontic Journal, 46, 413-418.

Berdowska, I., Zielinski, B., Fecka, I., Kulbacka, J., Saczko, J., \& Gamian, A. (2013). Cytotoxic impact of phenolics from Lamiaceae species on human breast cancer cells. Food Chemistry, 141, 1313-1321.

Berrington, D., \& Lall, N. (2012). Anticancer activity of certain herbs and spices on the cervical epithelial carcinoma (HeLa) cell line. Evidence-based Complementary and Alternative Medicine, 2012, 564927.

Buyukleyla, M., \& Rencuzogullari, E. (2009). The effects of thymol on sister chromatid exchange: Chromosome aberration and micronucleus in human lymphocytes. Ecotoxicology and Environmental Safety, 72, 943-947.

CLSI (2002). Reference method for broth dilution in tests for determining the sensitivity to antifungal therapy of yeastApproved standard, CLSI document M27-A2 (2nd ed.). USA: CLSI.

CLSI (2003). Methods for dilution antimicrobial susceptibility tests for bacteria that grow aerobicallyApproved standard, CLSI document M7-A6 (6th ed.). USA: CLSI.

CLSI (2012). Reference method for broth dilution antifungal susceptibility testing of yeasts. Fourth informational supplement M27-S4. USA: CLSI.

Calò, R., Visone, C. M., \& Marabin, L. (2015). Thymol and Thymus vulgaris L: Activity against UVA- and UVB-induced damage in NCTC 2544 cell line. Mutation Research Genetic Toxicology and Environmental Mutagenesis, 791, 30-37.

Chotirmall, S. H., O'Donoghue, E., Bennett, K., Gunaratnam, C., O'Neill, S. J., \& McElvaney, N. G. (2010). Sputum Candida albicans presages $\mathrm{FEV}_{1}$ decline and hospital-treated exacerbations in cystic fibrosis. Chest, 138, 1186-1195.

Cuesta, A. I., Jewtuchowicz, V., Brusca, M. I., Nastri, M. L., \& Rosa, A. C. (2010). Prevalence of Staphylococcus spp and Candida spp in the oral cavity and periodontal pockets of periodontal disease patients. Acta Odontológica Latinoamericana, 23, $20-26$.

Ding, Z., Yang, X., Pater, A., \& Tang, S. C. (2000). Resistance to apoptosis is correlated with the reduced caspase- 3 activation and enhanced expression of antiapoptotic proteins in human cervical multidrug-resistant cells. Biochemical and Biophysical Research Communications, 270, 415-420.

Duncan, R., \& Richardson, S. C. (2012). Endocytosis and intracellular trafficking as gateways for nanomedicine delivery: Opportunities and challenges. Molecular Pharmaceutics, 9, 2380-2402.

Esmaeilbeig, M., Kouhpayeh, S. A., \& Amirghofran, Z. (2015). An investigation of the growth inhibitory capacity of several medicinal plants from Iran on tumor cell lines. Iranian Journal of Cancer Prevention, 8, e4032.

Esmaeili-Mahani, S., Falahi, F., \& Yaghoobi, M. M. (2014). Proapoptotic and antiproliferative effects of Thymus caramanicus on human breast cancer cell line (MCF-7) and its interaction with anticancer drug vincristine. Evidence-based Complementary and Alternative Medicine, 2014, 893247.

Giarratana, F., Muscolino, D., Beninati, C., Giuffrida, A., \& Panebianco, A. (2014) Activity of Thymus vulgaris essential oil against Anisakis larvae. Experimental Parasitology, 142, 7-10.

Hammad, M., Sallal, A. K., \& Darmani, H. (2007). Inhibition of Streptococcus mutans adhesion to buccal epithelial cells by an aqueous extract of Thymus vulgaris. International Journal of Dental Hygiene, 5, 232-235.

Harriott, M. M., \& Noverr, M. C. (2009). Candida albicans and Staphylococcus aureus form polymicrobial biofilms: Effects on antimicrobial resistance. Antimicrobial Agents and Chemotherapy, 53, 3914-3922.

Ismaili, H., Milella, L., Fkih-Tetouani, S., Ilidrissi, A., Camporese, A., Sosa, S., et al. (2004). In vivo < /it > topical anti-inflammatory and in vitro antioxidant activities of two extracts of Thymus satureioides leaves. Journal of Ethnopharmacology, 91, $31-36$.

Jamali, C. A., El Bouzidi, L., Bekkouche, K., Lahcen, H., Markouk, M., Wohlmuth, H., et al (2012). Chemical composition and antioxidant and anticandidal activities of essential oils from different wild Moroccan Thymus species. Chemistry \& Biodiversity, 9, 1188-1197.

Kars, M. D., Iseri, O. D., Gündüz, U., Ural, A. U., Arpaci, F., \& Molnár, J. (2006) Development of rational in vitro models for drug resistance in breast cancer and modulation of MDR by selected compounds. Anticancer Research, 26, 4559-4568.

Kavanaugh, N. L., \& Ribbeck, K. (2012). Selected antimicrobial essential oils eradicate Pseudomonas spp: And Staphylococcus aureus biofilms. Applied and Environmental Microbiology, 78, 4057-4061.

Khaledi, N., Taheri, P., \& Tarighi, S. (2015). Antifungal activity of various essential oils against Rhizoctonia solani and Macrophomina phaseolina as major bean pathogens. Journal of Applied Microbiology, 118, 704-717.

Khan, M. S., Ahmad, I., Cameotra, S. S., \& Botha, F. (2014). Sub-MICs of Carum copticum and Thymus vulgaris influence virulence factors and biofilm formation in Candida spp. BMC Complementary and Alternative Medicine, 14, 337.

Klinke, T., Guggenheim, B., Klimm, W., \& Thurnheer, T. (2011). Dental caries in rats associated with Candida albicans. Caries Research, 45, 100-106.

Kohiyama, C. Y., Yamamoto Ribeiro, M. M., Mossini, S. A., Bando, E., da Silva Bomfim, N., Nerilo, S. B., et al. (2015). Antifungal properties and inhibitory effects upon aflatoxin production of Thymus vulgaris L. by Aspergillus flavus Link. Food Chemistry, 173, 1006-1010.

Lee, A. V., Oesterreich, S., \& Davidson, N. E. (2015). MCF-7 cells - changing the course of breast cancer research and care for 45 years. Journal of the National Cancer Institute, 107, 7 [pii: djv073].

Luzio, J. P., Pryor, P. R., \& Bright, N. A. (2007). Lysosomes: Fusion and function. Nature Reviews Molecular Cell Biology, 8, 622-632. 
Maissa, B. J., \& Walid, H. (2015). Antifungal activity of chemically different essential oils from wild Tunisian Thymus spp. Natural Product Research, 29, 869-873.

Marchant, S., Brailsford, S. R., Twomey, A. C., Roberts, G. J., \& Beighton, D. (2001). The predominant microflora of nursing caries lesions. Caries Research, 35, 397-406.

Mason, K. L., Erb Downward, J. R., Falkowski, N. R., Young, V. B., Kao, J. Y., \& Huffnagle, G. B. (2012). Interplay between the gastric bacterial microbiota and Candida albicans during postantibiotic recolonization and gastritis. Infection and Immunity, 80, 150-158.

Mastropaolo, M. D., Evans, N. P., Byrnes, M. K., Stevens, A. M., Robertson, J. L., \& Melville, S. B. (2005). Synergy in polymicrobial infections in a mouse model of type 2 diabetes. Infection and Immunity, 73, 6055-6063.

Melo, A. D., Amaral, A. F., Schaefer, G., Luciano, F. B., de Andrade, C., Costa, L. B., et al. (2015). Antimicrobial effect against different bacterial strains and bacterial adaptation to essential oils used as feed additives. Canadian Journal of Veterinary Research, 79, 285-289.

Morales, D. K., Grahl, N., Okegbe, C., Dietrich, L. E., Jacobs, N. J., \& Hogan, D. A. (2013). Control of Candida albicans metabolism and biofilm formation by Pseudomonas aeruginosa phenazines. mBio, 4, e00526-12.

O'Connell, H. A., Kottkamp, G. S., Eppelbaum, J. L., Stubblefield, B. A., Gilbert, S. E., \& Gilbert, E. S. (2006). Influences of biofilm structure and antibiotic resistance mechanisms on indirect pathogenicity in a model polymicrobial biofilm. Applied and Environmental Microbiology, 72, 5013-5019.

Ocaña, A., \& Reglero, G. (2012). Effects of thyme extract oils (from Thymus vulgaris, Thymus zygis, and Thymus hyemalis) on cytokine production and gene expression of oxldl-stimulated thp -1-macrophages. Journal of Obesity, 104706.

Pereira-Cenci, T., Deng, D. M., Kraneveld, E. A., Manders, E. M., Del Bel Cury, A. A., ten Cate, J. M., et al. (2008). The effect of Streptococcus mutans and Candida glabrata on Candida albicans biofilms formed on different surfaces. Archives of Oral Biology, 53, 755-764.

Rahbari, R., Sheahan, T., Modes, V., Collier, P., Macfarlane, C., \& Badge, R. M. (2009). A novel L1 retrotransposon marker for HeLa cell line identification. Bio Techniques, 46, 277-284.

Ramage, G., Mowat, E., Jones, B., Williams, C., \& Lopez-Ribot, J. (2009). Our current understanding of fungal biofilms. Critical Reviews in Microbiology, 35, 340-355.

Sánchez, G., \& Aznar, R. (2015). Evaluation of natural compounds of plant origin for inactivation of enteric viruses. Food and Environmental Virology, 7, 183-187.

Silva, N., Alves, S., Gonçalves, A., Amaral, J. S., \& Poeta, P. (2013). Antimicrobial activity of essential oils from Mediterranean aromatic plants against several foodborne and spoilage bacteria. Food Science and Technology International, 19, 503-510.
Silva, A. M., Machado, I. D., Santin, J. R., de Melo, I. L., Pedrosa, G. V., Genovese, M. I., et al. (2015). Aqueous extract of Rosmarinus officinalis L. inhibits neutrophil influx and cytokine secretion. Phytotherapy Research, 29, 125-133.

Sun, M., Kang, Q., Li, T., Huang, L., Jiang, Y., \& Xia, W. (2014). Effect of high-fructose corn syrup on Streptococcus mutans virulence gene expression and on tooth demineralization. European Journal of Oral Sciences, 122, 216-222.

Tsai, M. L., Lin, C. C., Lin, W. C., \& Yang, C. H. (2011). Antimicrobial, antioxidant, and anti-inflammatory activities of essential oils from five selected herbs. Bioscience Biotechnology and Biochemistry, 75, 1977-1983.

Undeğer, U., Başaran, A., Degen, G. H., \& Başaran, N. (2009). Antioxidant activities of major thyme ingredients and lack of (oxidative) DNA damage in V79 Chinese hamster lung fibroblast cells at low levels of carvacrol and thymol. Food and Chemical Toxicology, 47, 2037-2043.

Zuanazzi, D., Souto, R., Mattos, M. B., Zuanazzi, M. R., Tura, B. R., Sansone, C., et al. (2010). Prevalence of potential bacterial respiratory pathogens in the oral cavity of hospitalised individuals. Archives of Oral Biology, 55, 21-28.

da Silva-Boghossian, C. M., do Souto, R. M., Luiz, R. R., \& Colombo, A. P. (2011). Association of red complex, A. actinomycetemcomitans and non-oral bacteria with periodontal diseases. Archives of Oral Biology, 56, 899-906.

de Carvalho, F. G., Silva, D. S., Hebling, J., Spolidorio, L. C., \& Spolidorio, D. M. (2006). Presence of mutans streptococci and Candida spp: In dental plaque/dentine of carious teeth and early childhood caries. Archives of Oral Biology, 51, 1024-1028.

de Las Mercedes, O. M., Carezzano, M. E., Giuliano, M., Daghero, J., Zygadlo, J., Bogino, P., et al. (2015). Antimicrobial activity of essential oils of Thymus vulgaris and Oreganum vulgare on phytopathogenic strains isolated from soybean. Plant Biology (Stuttgart Germany), 17, 758-765.

de Oliveira, J. R., de Castro, V. C., das Graças Figueiredo Vilela, P., Camargo, S. E., Carvalho, C. A., Jorge, A. O., et al. (2013). Cytotoxicity of Brazilian plant extracts against oral microorganisms of interest to dentistry. BMC Complementary and Alternative Medicine, 13, 208.

de Oliveira, J. R., de Aguiar Almeida, R. B., das Graças Figueiredo Vilela, P., de Oliveira, F. E., da Rocha, R. F., Jorge, A. O., et al. (2014). Control of microorganisms of oral health interest with Arctium lappa L. (burdock) extract non-cytotoxic to cell culture of macrophages (RAW 264. 7). Archives of Oral Biology, 59, 808-814.

de Oliveira, J. R., de Jesus, D., Figueira, L. W., de Oliveira, F. E., Pacheco Soares, C., Camargo, S. E., et al. (2017). Biological activities of Rosmarinus officinalis L. (rosemary) extract as analyzed in microorganisms and cells. Experimental Biology and Medicine (Maywood), 242, 625-634. 